\title{
UTILIZATION OF CEMENT WASTE IN STABILIZATION OF SOILS FOR ROAD CONSTRUCTION
}

\author{
T. Al-Refeai and A. Al-Suhaibani
}

\begin{abstract}
Cement Kiln Dust (CKD) from Al-Yamamah Cement plant in Riyadh, was added to different soils (A-4, A-2-4, and A-I-b) to study its stabilizing effect on the properties of these soils. It was found, in general, and for the CKD contents used ( 4,10 , and 16\%) that CKD lowers plasticity, increases $\mathrm{pH}$ value, increases optimum moisture content and lowers the maximum dry density of those soils. There was an increase in California bearing ratio (CBR) and unconfined compressive strength due to CKD addition. Increasing the amount of CKD further increases its effect on the above properties.

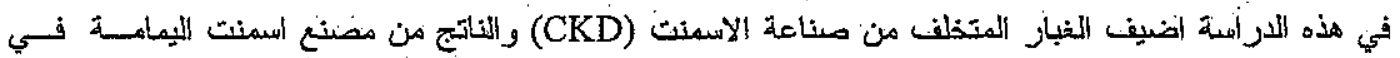

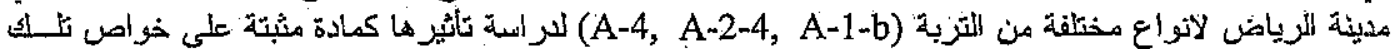

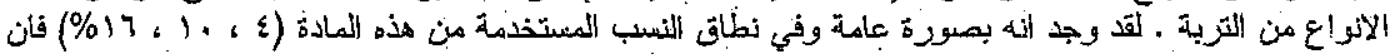

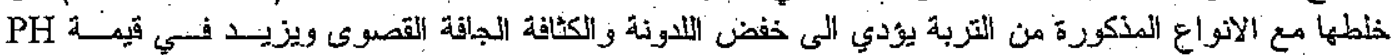

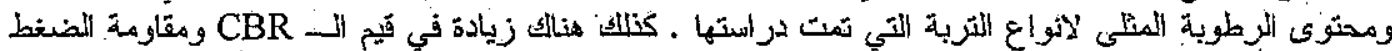

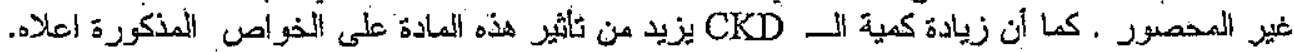

Keywords: Cement Kiln Dust, Soil stabilization, Moisture content, Dry density and conipressive strength.

\section{INTRODUCTION}

Enormous quantitjes of domestic and industrial waste are generated annually in Saudi Arabia. There are three techniques for disposal of these waste materials: (a) recycling, (b) incineration and (c) burial. The published data on current practice indicate that the bulk of industrial refuse is land filled. Saudi's Portland cement industry now produce about 1.2 million tons of kiln dust annually, and this figure is forecasted to increase because of increased demand for Portland cement and the expansion of existing plants. Rising consciousness of the environment is making it more and more difficult to find places to dispose of it, and in order to deal with this waste that is expected to increase in the future, it is vital to develop the technology needed to recycle large amounts of it as civil engineering material.

In recent years, use of waste products in highway construction has gained considerable attention as waste disposal continues to have a negative impact on the environment, disposal costs escalate, and traditional material become scarce and expensive. In this context, A SABIC'S (Saudi Basic Industries Corporation) - funded project was undertaken to determine the feasibility of utilizing cement kiln dust (CKD) produced by Al-Yamamah Saudi Cement Company in Riyadh as a cementitious material for stabilized base or subbase application and as mineral

Engineering Research Journal, Vol. 32, No. 1 January 2009, PP 67-76

(C) Faculty of Engineering, Minoufiya University, Egypt filler in asphalt concrete mixes. The CKD materials were mixed with soil to produce stabilized materials and with asphalt concrete to modify it. In this paper only the first part is reported; namely utilization of CKD materials to stabilize soils to be used as bases and subbases for road construction.

\section{BACKGROUND}

As the world population grows, so do the amount and type of waste being generated. Many of the wastes produced today will remain in the environment for a long period. The creation of nondecaying waste materials, combined with a growing consumer population, has resulted in a waste disposal crisis. One solution to this crisis lies in recycling waste into useful products.

Utilization of waste as construction materials is advocated to be an effective strategy based on a viewpoint of environmental geotechnology and a variety of researches and developments on waste application by proper treatment method has been carried out in the United States, Europe and Japan (Chesner and Eighmy 1991, Schoroder 1994, and Kamon and Katusmi 1994).

The total annual production of Portland cement in Saudi Arabia has increased from 0.667 million tons in 1960 to more than 14.3 million tons in 1995 , and is expected to exceed 20 million tons in 20012 . A by- 
product of Portland cement manufacturing is produced in a huge amount of dust, namely cement kiln dust (CKD). The figures on CKD production are not precise. CKD production in Saudi Arabia is now estimated to be $1.2-1.4$ million tons per year. This present quantity is projected to continue to increase in the future due to the ever increasing cement production and recent restrictions on air pollution in the Kingdom. These waste materials are dumped on large areas. In recent years, use of various waste products in ground construction has gained considerable attention worldwide in view of increasing costs of waste disposal, and environmental constraints.

\subsection{Cement Kiln Dust}

Cement Kiln Dust (CKD) is a by-product of Portland cement high-temperature rotary kiln production operations that captured in the air pollution control dust collection system (e.g., cyclones, electrostatic precipitators, and baghouses). It is generated from burning the raw materials in a rotary kiln to produce clinker. The production of one ton of cement involves the commination of about 2.6 to 2.8 tons of raw materials. Between 5 and $10 \%$ of these finely pulverized materials will be agitated and thus suspended as dust in gases (Labahn, 1983). Generally, for each one ton of clinker, a typical kiln generates around $0.06-0.07$ ton of CKD (Al-Refeai and Al-Kami, 1999).

The primary value of cement kiln dusts is their cementitious properties. Depending on the concentration of hydratable oxides present in the $C K D$, primarily unreacted or free lime $(\mathrm{CaO})$ and free magnesia (MgO), cement kiln dust can be highly cementitious.

The chemical and physical characteristics of CKD that is collected for use outside of the cement production facility will depend in great part on the method of dust collection employed at the facility. Free lime can be found in CKD, and its concentration is typically highest in the coarser particles captured closest to the kiln. Finer particles tend to exhibit higher concentrations of sulfates and alkalis. If the coarser particles are not separated out and returned to the kiln, the total dust will be higher in free lime (since it will contain some coarse particles). CKD from wet-process kilns also tends to be lower in calcium content than dust from dry-process kilns.

\subsection{Disposal and Recycling of CKD}

At the present time, approximately 80 percent of the surplus CKD remaining after reuse in cement manufacturing in the United States is stockpiled or land filled (Ciesielski and Collins, 1984). Most of the CKD generated in Saudi Arabia is currently disposed of in stockpiles or landfills (Al-Refeai, 2000).
Most of the CKD produced in the United States is reused within the cement plant. About 64 percent of the total CKD generated (or about 8.3 million metric tons) is used in this fashion (USEPA, 1983). Approximately 6 percent of the total CKD generated is utilized off-site. The most common beneficial use of CKD is its use as a stabilizing agent for wastes, where its absorptive capacity and alkaline properties can reduce the moisture content, increase the bearing capacity, and provide an alkaline environment for waste materials.

Cement kiln dusts have been used as stabilizing and solidifying agents in the treatment of soft or wet soils for engineering purposes (Davis and Hooks, 1974) and for environmental remediation (Mackay and Emery, 1994). CKD have also been used as pozzolan initiators, as a pellatized lightweight aggregate material, as a mineral filler in asphalt pavements, and as a fill material in earth embankments.

A significant potential reuse for CKD exists for its use as a soil conditioner for agricultural purposes (in lieu of agricultural lime) and as an acidneutralizing agent in agricultural and water treatment applications. However, at the present time, the US EPA is evaluating the possible need to regulate the use of $\mathrm{CKD}$ in this application.

\subsection{Utilization of CKD in Soil Stabilization}

The utilization of cement kiln dust in soil stabilization has received increasing attention. Zaman et al. (1992) showed that soil stabilization using cement kiln dust results in a significance reduction in the plasticity index, free swell and an increase in the $\mathrm{CBR}$ and in the unconfined compressive strength of a highly expansive clay. Miller et al. (1997) found that cement kiln dust is a potentially useful additive for reducing wettinginduced collapse settlement and for reducing overall compressibility of compacted shale. Al-Refeai and Al-Karni (1999) reported that treatment with cement kiln dust resulted in significant improvement in the engineering properties of three problematic soils found in central region of Saudi Arabia. Al-Refeai (1998) investigated the effectiveness of cement kiln dust in stabilizing expansive and soft cohesive soils.

Al-Refeai (2000) found that cement-kiln dust is a promising material in stabilization of cohesive soft soil. With the addition of a proper anount of stabilizer and by allowing the nixture to cure for a sufficient period of time, cement-kiln dust stabilization produced better improvement in consistency characteristics, strength and stiffness than lime stabilization.

Fatani and Khan (1990) utilized cement kiln dust in stabilizing dune sand-asphalt mixes. Addition of cement kiln dust to various types of soil has been 
found - in the above studies - to be beneficial to enhance the strength, compressibility; swelling, collapse resistance of soils.

\subsection{Utilization of CKD in Stabilizing Bases}

CKD has been used as a cementitious material or a pozzolan activator in stabilized base applications. As a cementitious material, CKD can replace or be used in combination with Portland cement. As a pozzolan activator, CKD can replace or be used in combination with Portland cement or hydrated lime. Limited research data on the use of CKD for stabilized base have been reported (Ciesielski and Collins, 1994).

\section{MATERIALS USED IN THE RESEARCH}

\subsection{Cement Kiln Dust}

The cement kiln dist used in this research was obtained from Al-Yamamah Saudi Cement Company in Riyadh. A comprehensive laboratory testing program was performed on collected dust samples. Laboratory tests conducted, in accordance with ASTM testing procedure whenever possible, include chemical composition, grain size distribution, specific gravity, Atterberg limits, moisture-density relationship and $\mathrm{pH}$ value.

\subsection{Soils}

Different soil samples collected from sites around the city of Riyadh were used in this research. The study considered three types of soil namely: (1) $A-4$, (2) A-2-4 and (3) A-1-b as classified by AASHTO soil classification system. Laboratory tests conducted in accordance with ASTM testing procedure on untreated and dust treated soils including grain size distribution, specific gravity, Atterberg limits, moisture-density relationship, unconfined compressive strength, California bearing ratio, durability, and permeability

\section{MATERIALS CHARACTERIZATION}

\subsection{Cement Kiln Dust}

Cement kiln dust used in this study was collected from the dumping site from a single day waste production. Four samples designated as $\mathrm{S} 1, \mathrm{~S} 2, \mathrm{~S} 3$ and S4 (shown in Table 1, were collected that represent CKD from different kilns, enough amount of S2 sample was collected and used in this study. Chemical compositions of collected samples are shown in Table 1 along with typical composition of ordinary Portland cement. The variability of collected CKD from different kilns appears very small. Note that there are the significant amounts of cement-forming oxides in the CKD samples, close to the oxide amounts found in Portland cement. The CKD samples contain significant anount of calcium oxide that gives it good cementing characteristics.
Total calcium oxide includes both bound and free lime, and loss on ignition (loI) gives an indirect indication of lime available for reaction. If loss on ignition is high, generally there is more water bound in the structure of the CKD, which is driven off upon heating. If more water is present (high LOI) then less of the total calcium oxide is available as free lime for reaction (Miller and Zaman 2000).

The chemical composition of the cement kiln dust used in this study is similar to other Saudi CKD and that reported in the literatures as shown in Table 2.

Table 1 Chemical Composition of CKD Samples

\begin{tabular}{|c|c|c|c|c|c|}
\hline \multirow{2}{*}{ Oxide } & \multicolumn{4}{|c|}{$\begin{array}{c}\text { Bypass Cement kiln dust } \\
\text { samples }\end{array}$} & \multirow{2}{*}{$\begin{array}{l}\text { Ordiuary* } \\
\text { Portland } \\
\text { cement }\end{array}$} \\
\hline & S1 & S2 & s3 & $\$ 4$ & \\
\hline $\begin{array}{c}\text { Silicon Dioxide, } \mathrm{SiO}_{2} \\
(\%)\end{array}$ & 17.59 & 16.37 & 19.08 & 16.08 & 22 \\
\hline $\begin{array}{l}\text { Aluminum Oxide, } \\
\qquad \mathrm{Al}_{2} \mathrm{O}_{3}(\%)\end{array}$ & 7.07 & 6.72 & 7.62 & 6.74 & 6 \\
\hline Iron Oxide, $\mathrm{Fe}_{2} \mathrm{O}_{3}(\%)$ & 2.90 & 2.87 & 2.93 & 2.862 & 2.5 \\
\hline $\begin{array}{c}\text { Total Calcium Oxide, } \\
\mathrm{CaO}(\%)\end{array}$ & 63.09 & 62.93 & 64.27 & 62.93 & 63 \\
\hline $\begin{array}{l}\text { Magnesium Oxide, } \\
\text { MgO (\%) }\end{array}$ & 0.66 & 0.61 & 0.79 & 0.63 & 2.6 \\
\hline $\begin{array}{l}\text { Sulfur Trioxide, } \mathrm{SO}_{3} \\
\text { (\%) }\end{array}$ & 239 & 2.39 & 2.91 & 2.66 & 2 \\
\hline $\begin{array}{c}\text { Sodium Oxide, } \mathrm{Na}_{2} \mathrm{O} \\
(\%)\end{array}$ & 0.69 & 0.39 & 1.01 & 0.54 & 0.3 \\
\hline $\begin{array}{c}\text { Potassium Oxide, } \\
\mathrm{K}_{2} \mathrm{O}(\%)\end{array}$ & 0.25 & 0.21 & 0.25 & 0.21 & 0.6 \\
\hline Loss on Ignition & & & & & \\
\hline
\end{tabular}

- Mindess and Young (1981)

Table 2 Typical Chemical Composition of CKD

\begin{tabular}{|c|c|c|c|c|c|c|}
\hline Source & \multicolumn{4}{|c|}{ Saudi Arabia } & \multirow[b]{2}{*}{$U_{S A}{ }^{2}$} & \multirow[b]{2}{*}{$\begin{array}{l}\text { Used } \\
\text { CikD }\end{array}$} \\
\hline $\begin{array}{l}\text { Chemical } \\
\text { Analysis }\end{array}$ & Riyadh & Dammam & Y'anbue & Abuha & & \\
\hline $\mathrm{SiO}_{2} \%$ & 15.7 & 14.3 & 36.9 & $\overline{17.7}$ & 14,43 & 16.37 \\
\hline$\overline{\mathrm{Al}} \mathrm{l}_{2} \mathrm{O}_{3} \%$ & 5.0 & 4.8 & 5.8 & 5.3 & 4.05 & 6.72 \\
\hline $\mathrm{Al}_{2} \mathrm{O}_{3} \%$ & 2.41 & 3.6 & 3.5 & 3.0 & 1.42 & 2.87 \\
\hline $\mathrm{CaO} \%$ & 63.6 & 64.4 & 56.7 & 54.8 & 4.65 & 62.93 \\
\hline $\mathrm{MgO} \%$ & 0.73 & 1.14 & 1.2 & 1.33 & 1.51 & 0.61 \\
\hline $\mathrm{SO}_{3} \%$ & 1.97 & 5.61 & 4.2 & 4.06 & $4 . \overline{95}$ & 2.39 \\
\hline $\mathrm{Na}_{2} \mathrm{O} \%$ & 0.26 & 0.20 & 0.26 & 0.20 & $\overline{0.34}$ & $\overline{0.39}$ \\
\hline $\mathrm{K}_{2} \mathrm{O} \%$ & 1.33 & 1.67 & 1.09 & 1.38 & 1.86 & 0.21 \\
\hline $\begin{array}{l}\text { Loss on Ignition } \\
\%\end{array}$ & 8 & 3.3 & 9.8 & 11.66 & 28.04 & 8.3 \\
\hline
\end{tabular}

${ }^{1}$ Al-Refeai (2000) 
$\mathrm{CKD}$ is generally grayish in color of relatively uniform size and consists of predominantly silt-size, non-plastic particles with specific gravity of 2.90 , gradation of $94 \%$ passing No. 200 sieve and mean particle size of $0.01 \mathrm{~mm}$ as shown in Figure 1.

The Standard Proctor Compaction results of the CKD is shown in Figure 2, that shows a typically shaped curve with a single peak, with maximum dry density of $14.2 \mathrm{kN} / \mathrm{m}^{3}$ at an optimum moisture content of about $25 \%$.

The $\mathrm{pH}$ values for $\mathrm{A}-4$ soil treated with $C K D$ shown in Figure 3 are another indication of the high reactivity of the $\mathrm{CKD}$. Measurements of $\mathrm{pH}$ were conducted according to the method recommended for lime by Eades and Grim (1966). The first 5\% of CKD substantially increased the $\mathrm{pH}$ value of the treated soil to a level that is sufficiently high $(\mathrm{pH} \geq$ 12) that silica and alumina are dissolved from the clay minerals, from which new compounds are formed as a result of pozzolanic reactions. The silica and alumina within the clay structure react with the water and available free lime from the CKD to form cementing material. As a result of these reactions, the CKD-treated soil becomes stronger. The pozzolanic reaction may continue for a long period of time.

The most unique and outstanding characteristics of cement kiln dust are being pozzolanic and selfhardening. Strength gain for compacted CKD was determined using the unconfined compressive test. Figure 4 shows the strength development with time for compacted $\mathrm{CKD}$ at optimum moisture content (OMC) and maximum dry density (MDD) after normal curing. The initial slope of the strength-time curve is indicative of the early self-hardening characteristics of the CKD. Most of the strength gain for compacted $\mathrm{CKD}$ occurs within the first 7 days after compaction test.

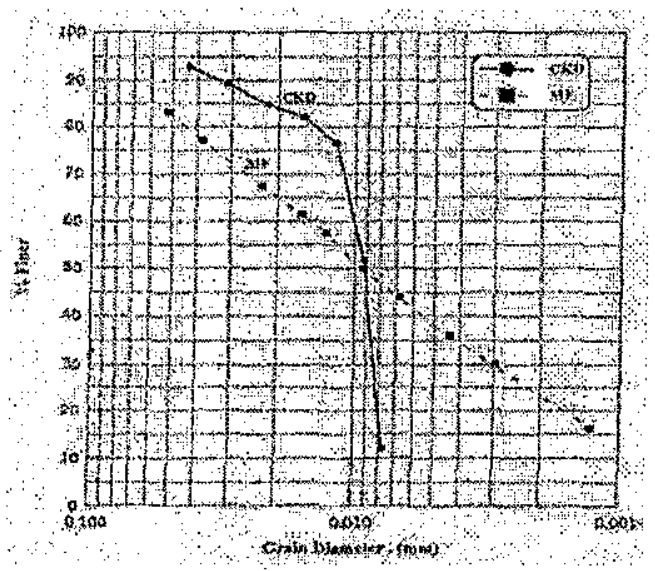

Figure 1 Grain size distribution curves for cement kiln dust and mineral filler

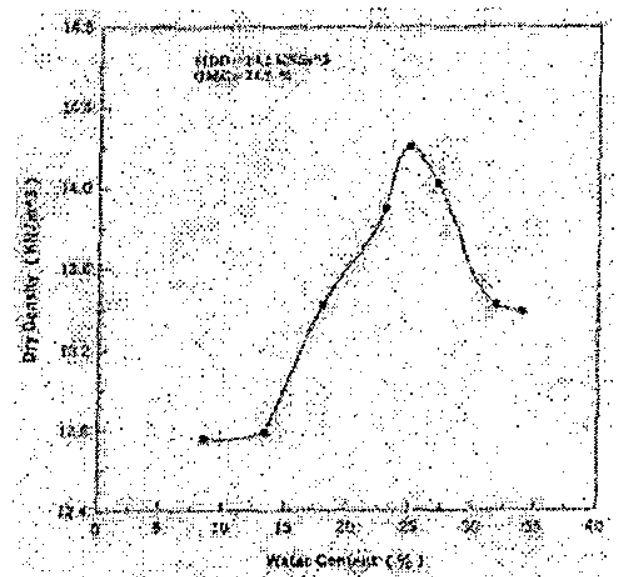

Figure 2 Standard compaction curve for cement kiln dust

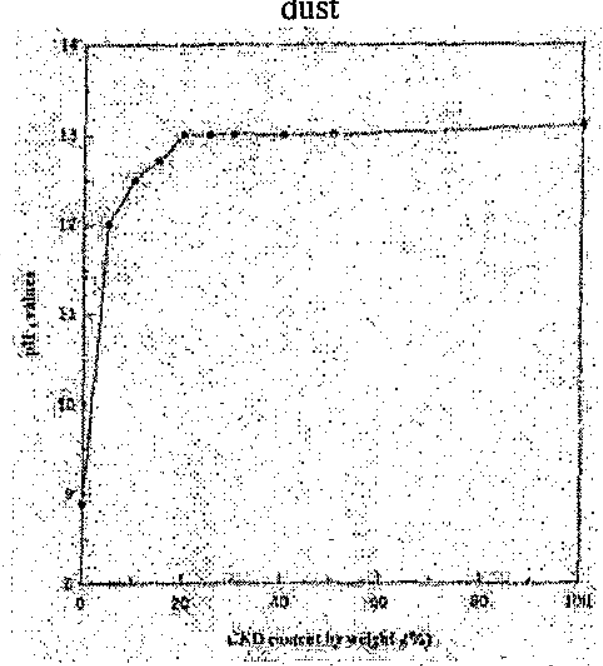

Figure $3 \mathrm{pH}$ values versus additive content for $(\mathrm{A}-4)$

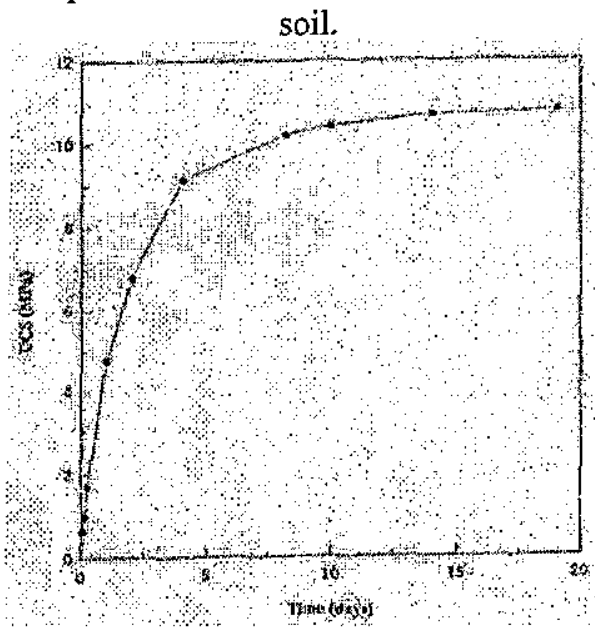

Figure 4 Variation of UCS with time for $100 \%$ $\mathrm{CKD}$ at $\mathrm{OMC}$ and $\mathrm{MDD}$.

\subsection{Soils}

Three soil types - silty sand with gravel $(A-1-b)$, clayey sand with gravel (A-2-4), and sandy lean clay (A-4) - representing the predominant soil series indigenous to Saudi Arabia were selected to evaluate the feasibility of disposing CKD for soil stabilization. The grain distribution curves for tested soils are 
shown in Figures 5 to 7. The compaction curves for the soil samples from Standard Proctor Compaction tests are shown in Figures 8 to 10 . The properties of these soils are presented in Table 3 .

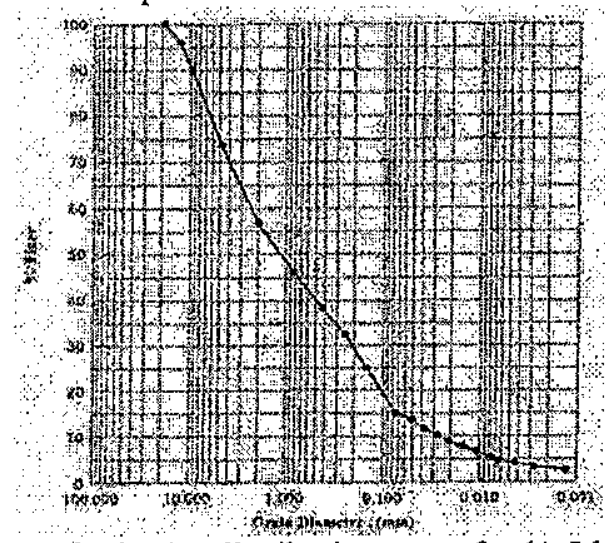

Figure 5 Grain size distribution curve for (A-I-b) soil

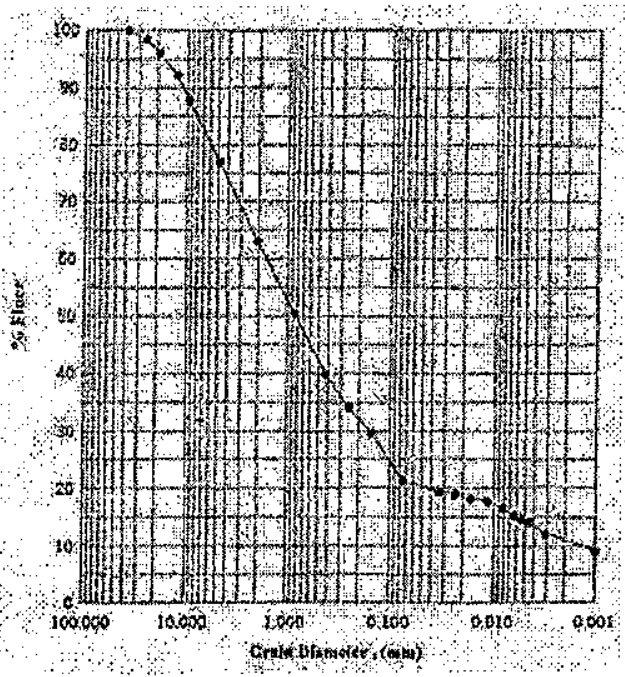

Figure 6 Grain size distribution curve for (A-2-4) soil.

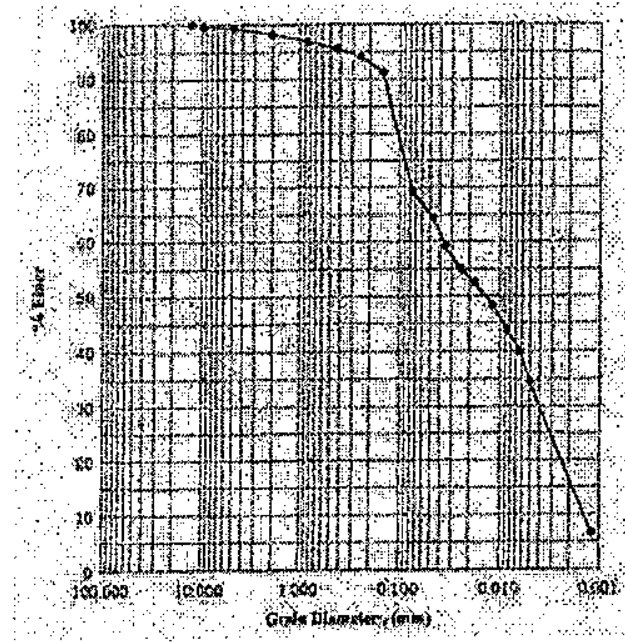

Figure 7 Grain size distribution tune for $(\mathrm{A}-4)$ soil.
Table 3 Physical Properties of Test Soils

\begin{tabular}{|l|l|l|l|}
\hline \multirow{2}{*}{ Property } & \multicolumn{3}{|c|}{ Soils } \\
\cline { 2 - 4 } & \multicolumn{1}{|c|}{1} & \multicolumn{1}{|c|}{2} & \multicolumn{1}{|c|}{3} \\
\hline AASHTO classification & A-1-b & A-2-4 & A-4 \\
\hline Unified classification & SM & SC & CL \\
\hline Gravel\% & 26.5 & 23.1 & -- \\
\hline Sand \% & 58.5 & 55.6 & 31 \\
\hline Fines(-sieve\$200)\% & 15 & 21.3 & 69 \\
\hline Clay (<.002 mm)\% & 3 & 12 & 17 \\
\hline Liquid limit \% & 19.1 & 25.5 & 26.5 \\
\hline Plasticity index \% & 1 & 8 & 7.5 \\
\hline Specific gravity & 2.69 & 2.81 & 2.81 \\
\hline Max. dry density (kN/m3) & 20.9 & 20.5 & 17.40 \\
\hline Opt. moisture content (\%) & 7.5 & 8.7 & 17.3 \\
\hline
\end{tabular}

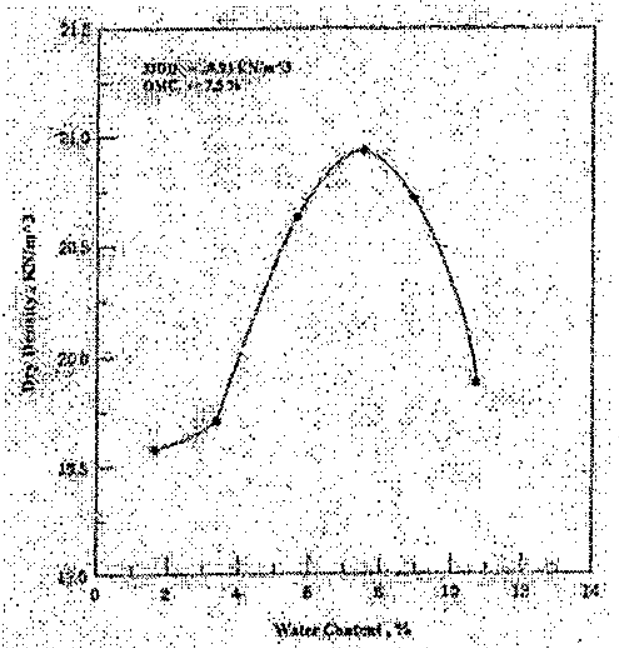

Figure 8 Standard compaction curve for $(A-1-b)$ soil.

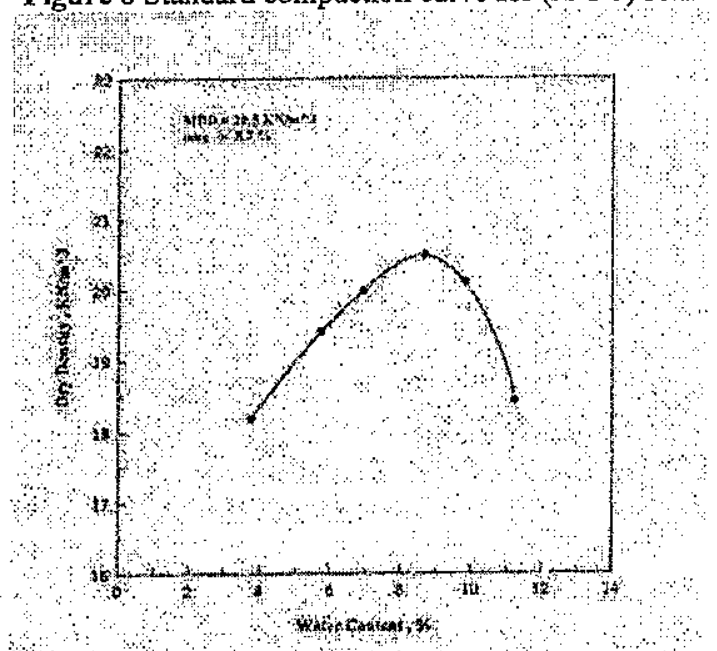

Figure 9 Standard compaction curve for (A-2-4) soil. 


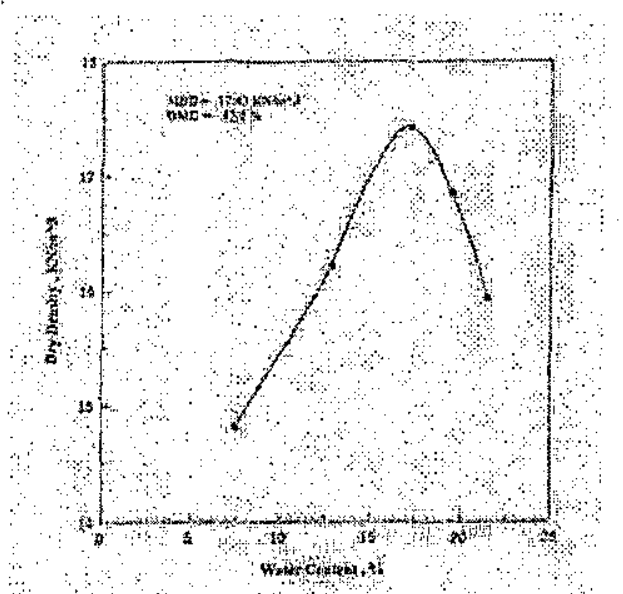

Figure 10 Standard compaction curve for (A-4) soil.

\section{PROPERTIES OF CKD TREATED SOILS}

\subsection{Effect on Atterberg Limits}

The Atterberg limit tests were performed on sandy lean clay (A-4) soil treated with different percentages of $\mathrm{CKD}$ to assess the effectiveness of $\mathrm{CKD}$ in reducing soil plasticity. The results are shown in Figure 11. The effect of CKD was similar to the typical affect of lime, that is, an increase in liquid limit and plastic limit with a decrease in plasticity index with the addition of CKD. However, at $\mathrm{CKD}$ content exceeding $4 \%$ further reduction of the soil plasticity is marginal as shown in Figure 11. In a previous investigation, Al-Refeai and Al-Karni (1999) found that the addition of $10 \%$ CKD to highly plastic bentonite clay resulted in a reduction of plasticity index from $180 \%$ to $100 \%$. With the reduction in soil plasticity, the engineering properties and workability of plastic clay are improved.

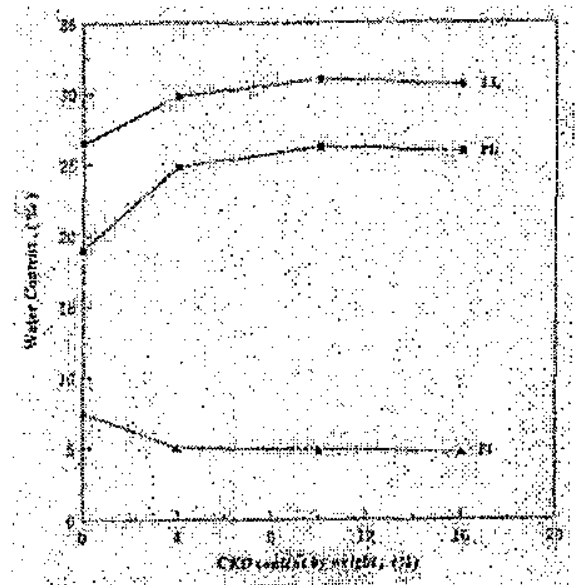

Figure 11 Effect of cement Kiln dust on plasticity characteristics of A-4 soil.

\subsection{Effect on pH}

It was observed that addition of CKD to soil affected its $\mathrm{pH}$ yalue. Figure 3 shows that CKD increases the $\mathrm{pH}$ value. CKD added in small quantities is sufficient to make the treated soil substantially alkaline, and the use of CKD exceeding $5 \%(\mathrm{pH}>12)$ can be detrimental, where excessive quantities of CKD raises the $\mathrm{pH}$ level above 12 , and this can be harmful to geotextile and reinforcement which are prone to degradation under highly acidic or alkaline environments.

\subsection{Effect on Compaction}

Compaction characteristics of mixtures of $\mathrm{CKD}$ and the three soil types were investigated by performing Standard Proctor Tests (ASTM D 698) at various levels of CKD contents $(0,4,10$ and $16 \%)$ with the treated soil being compacted as soon as practical after mixing. Figures 12-14 compare the compaction curves for these treated soils. For the three types of soil, the optimum water content of treated samples increases with increasing the amounts of CKD as shown in Figure 15. This behavior is similar to lime that tends to decrease the maximum dry density and increase the optimum water content of moist soil (Hausmann; 1990). This is because CKD similar to lime consumes water during the hydration, thereby increasing the optimum water content. Although the specific gravity of all three soils is less than that of the CKD, maximum dry density of CKD treated soils was lower than that of the untreated soil as shown in Figure 16. This reduction in dry density is generally attributed to the flocculation and agglomeration of the clay particles within the soil matrix.

In comparison with other soil types, A-2-4 specimens treated with $\mathrm{CKD}$ behave very differently. Addition of CKD makes the compaction curves flatter, which makes moisture content control in the field less critical and minimizes the variability of the density produced (Hausmann, 1990).

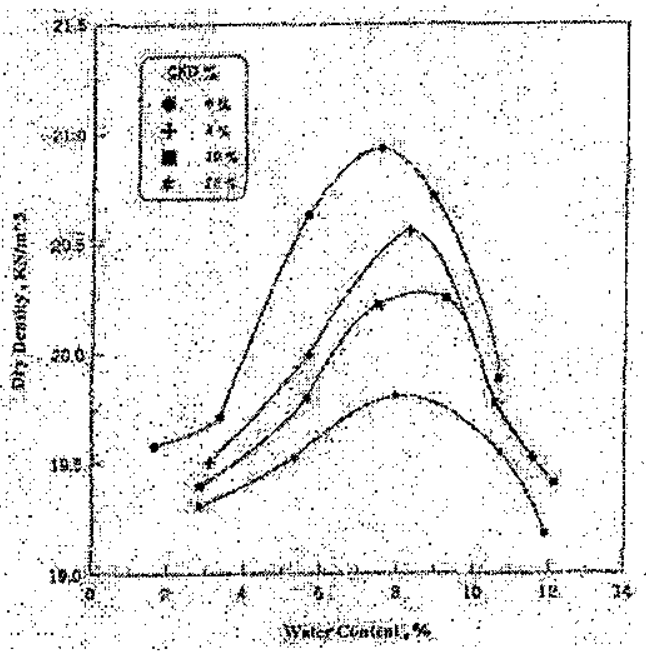

Figure 12 Effect of CKD \% on compaction characteristics of (A-1-b) soil. 


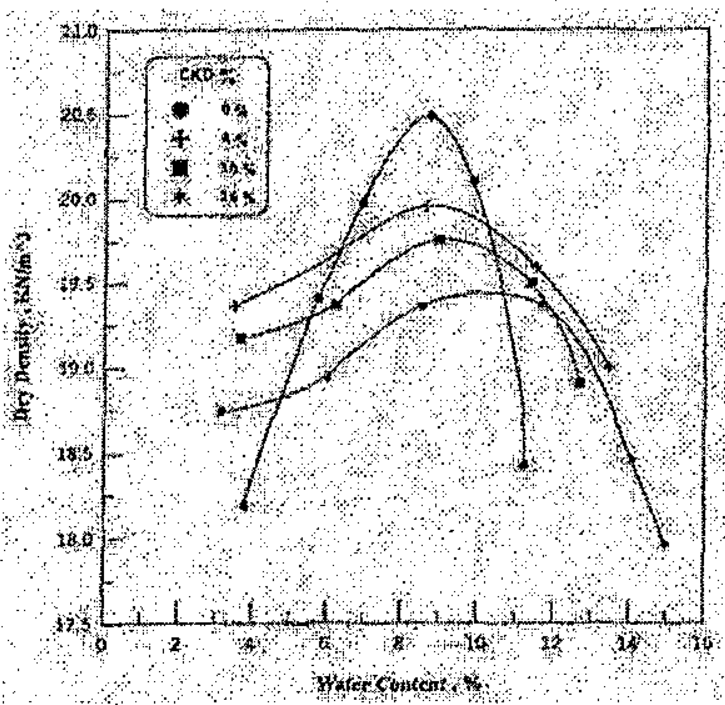

Figure 13 Effect of CKD \% on compaction characteristics of $(A-2-4)$ soil.

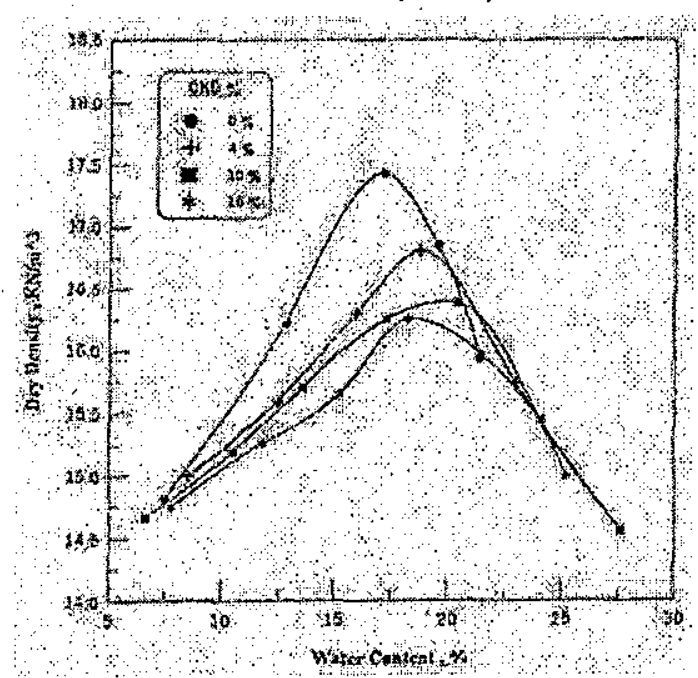

Figure 14 Effect of CKD on Compaction Characteristics of A-4 Soil.

\subsection{Effect on CBR}

The results of soaked $\mathrm{CBR}$ tests and soil samples treated with $0,4,10$ and $16 \% \mathrm{CKD}$ in addition to samples treated with 2 and $16 \%$ Portland cement are summarized in Table 4 . The A-4 soil had initially very low CBR value. With the addition of CKD there was a significant increase, where the CBR increased to 20.2 from 6.7 with the addition of $2 \%$ CKD. When $10 \%$ CKD was added, there was a dramatic increase in CBR of about $800 \%$, although, not as dramatic as cement, as shown in Figure 17. The CBR swell for treated soils was very small as summarized in Table 4.

\subsection{Effect on Unconfined Compression}

The compressive strength of treated soil is an important factor in evaluating the effectiveness of soil stabilization. Thomson (1968) showed that the unconfined compressive strength is a good indicator of other strength parameters and stress-strain moduli. Soil specimens treated with 0,$2 ; 4,10$ and $16 \% \mathrm{CKD}$ as well as $4 \%$ Portland cement were tested after 7 and 28 days of curing in unconfined compression. The results are shown in Figures 18 to 20 . From the curves presented in these figures, increasing $\mathrm{CKD}$ causes considerable increases in the unconfined strength of all treated soils and extended curing effects a notable increase in strangth. However, as the curing period gets longer the differences in the strength becomes quite significant at high CKD ratios. Ola (1978) suggested that treated soil with compressive strength of $1.8 \mathrm{MPa}$ can be considered as adequate for base material in the construction of low traffic road. Thus, it appears that the addition of $6.8 \%$ CKD to $A-1-b$ and $A-2-4$ soils is sufficient to enable the soils to fulfill the above function. The soil samples treated with $4 \%$ Portland cement indicate strength much higher than those stabilized with CKD.

The influence of time delay between mixing and compaction upon the maximum dry density and unconfined strength of A-2-4 soil treated with $10 \%$ CKD was investigated. The effect of delaying compaction - after mixing - up to 24 hours is shown in Figure 21.

Time delay before compaction, where compactive effort is held constant, results in loss of density, which in turn results in strength reduction as shown in Figure 22. Similar behavior has been noted by Maclean and Lewis (1963) for cement treated soils. Delay in compaction, which allows the hydration process to commence and thus build up the strength of treated soil, is a major cause of loss in strength because the CKD-soil mix becomes more difficult to compact and the final density achieved will, therefore, be lower (Ingles and Metcalf, 1977).

Table 4 CBR Test Results

\begin{tabular}{|c|c|c|c|c|c|c|}
\hline \multirow{2}{*}{$\begin{array}{c}\text { CKD } \\
\%\end{array}$} & \multicolumn{2}{|c|}{ A-1-b soil } & \multicolumn{2}{c|}{ A-2-4 soil } & \multicolumn{2}{c|}{ A-4 soil } \\
\cline { 2 - 7 } CBR \% & Swell \% & CBR \% & Swell \% & CBR \% & Swell \% \\
\hline 0 & 82 & 0.01 & 32.5 & 0.08 & 6.7 & 0.43 \\
\hline 2 & $*$ & - & 132 & 0.05 & 20.4 & 0.16 \\
\hline $2^{* *}$ & $*$ & - & $*$ & 0.04 & 83.2 & 0.06 \\
\hline 4 & $*$ & 0.03 & $*$ & 0.08 & 22.2 & 0.34 \\
\hline 10 & $*$ & & $*$ & 0.09 & 55.3 & 0.87 \\
\hline 16 & $*$ & & $*$ & 0.16 & 80.3 & 0.71 \\
\hline $16 * *$ & $*$ & & $*$ & 0.03 & $*$ & 0.04 \\
\hline
\end{tabular}

* Exremely high value (CBR $>100)$

** Portland cement 


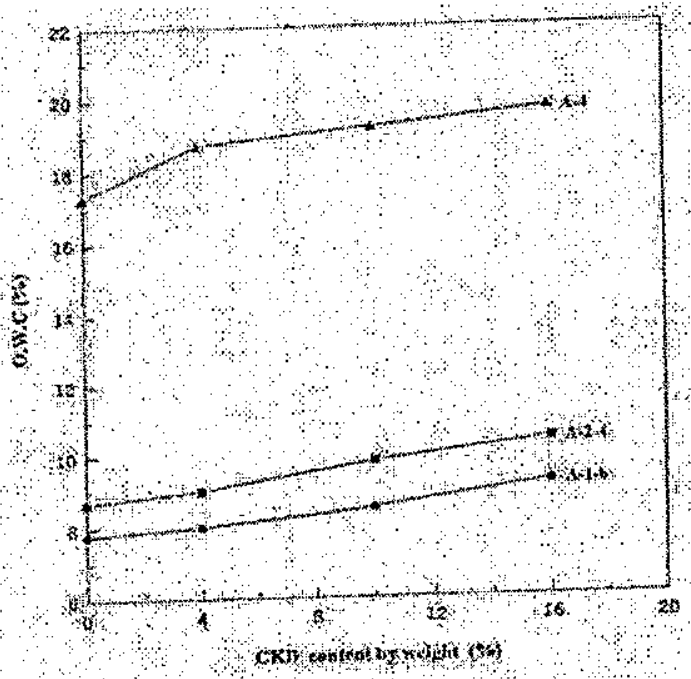

Figure 15 Effect of CKD content on optimum water content of treated soils.

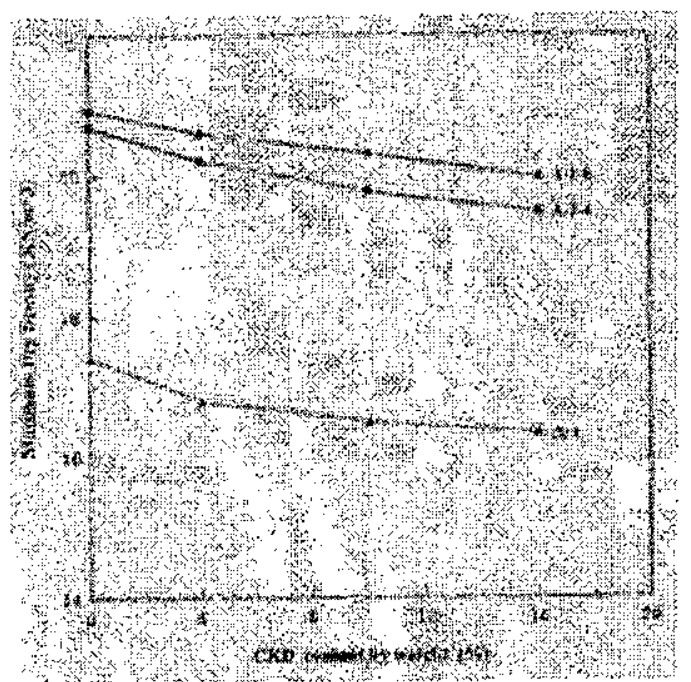

Figure 16 Effect of CKD content on maximum dry density of treated soils.

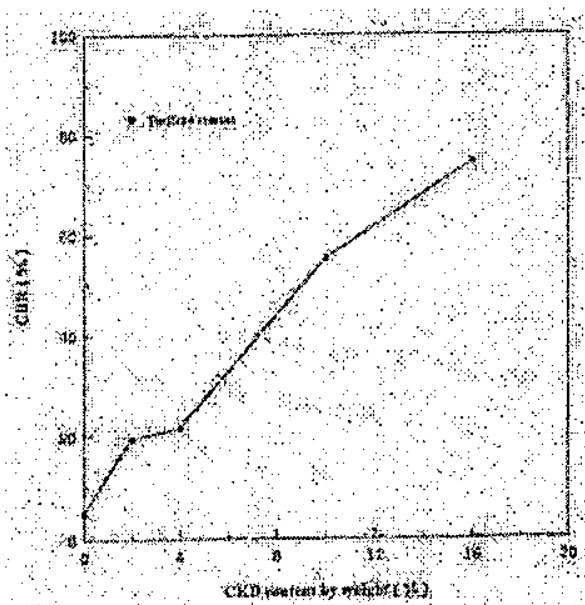

Figure 17 Effect of CKD content on CBR for (A-4) soil.

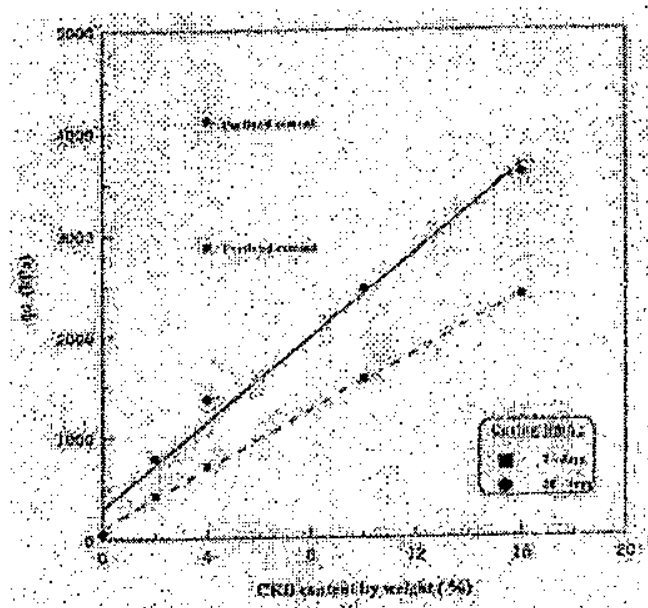

Figure 18 Effect of CKD content on unconfined compressive strength for (A-1-b) soil.

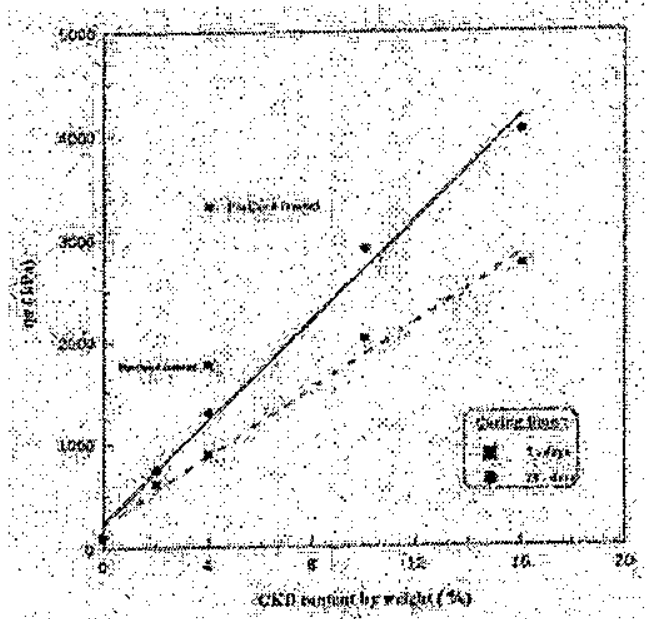

Figure 19 Effect of $\mathrm{CKD} \%$ on unconfined compressive strength for (A-2-4) soil.

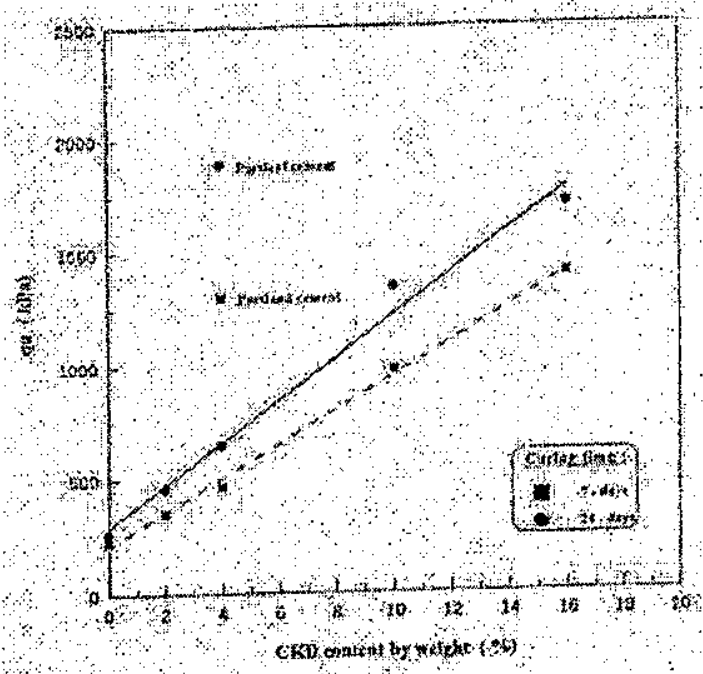

Figure 20 Effect of CKD \% on unconfined compressive strength for $(A-4)$ soil. 


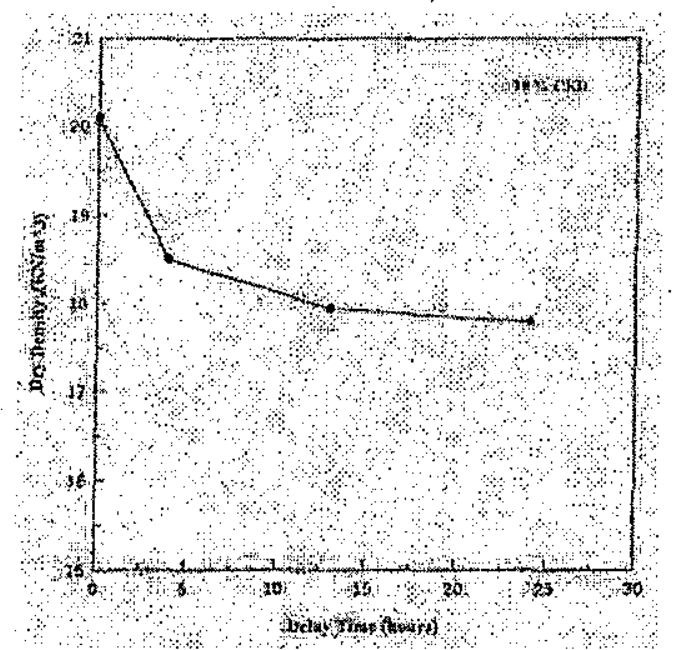

Figure 21 Effect of time delay on dry density of (A2-4) soil.

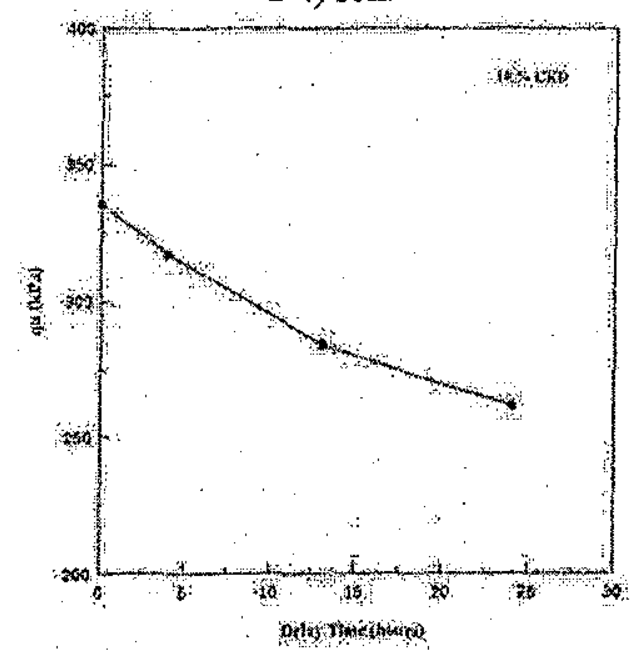

Figure 22 Effect of time delay on unconfined compressive strength of (A-2-4) soil.

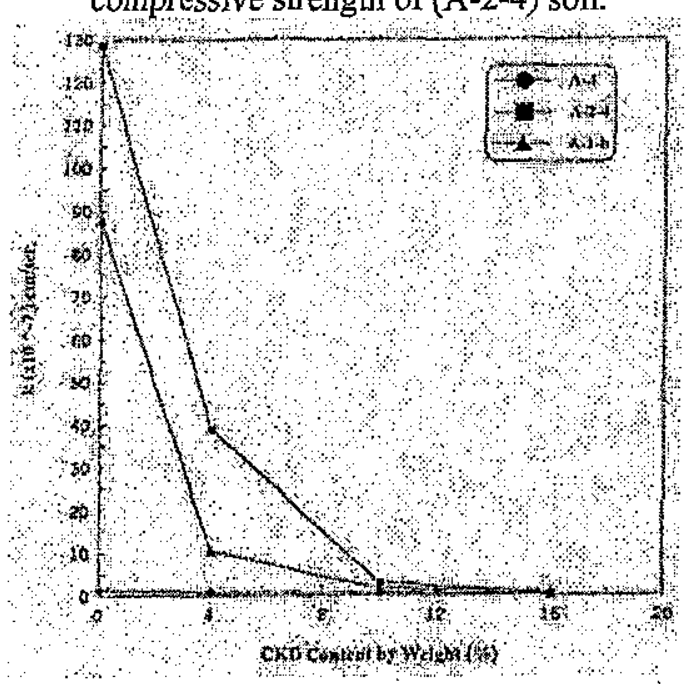

Figure 23 Effect of cement klin dust on the coefficient of permeability for treated soil.

\subsection{Effect on Permeability}

The permeability results of the three soils treated with CKD and compacted to the maximum dry density at optimum moisture content are shown in Figure 23. For the A-4 soil with relatively initial low permeability the addition of CKD does not affect the permeability of the treated soil. However, with the addition of $4 \%$ to A-1-b and A-2-4 soils there was a sharp decrease in the permeability of treated soils. It can be seen that there is a slight decrease in permeability with an increase in CKD content up to limiting value of $10 \%$. Thus it is anticipated that concentrations of elements in leachate from compacted CKD-treated soil would be significantly reduced.

\subsection{Effect on Durability}

Durability of CKD-stabilized soils was assessed by brush tests on wet-dry specimens; where percentage weight loss is calculated after 12 cycles of wetting-drying for the soil samples with 10 and $16 \%$ CKD and compacted to maximum dry density at optimum moisture content. Durability test results for the tested specimens are summarized in Table 5. The maximum weight loss in the brush test is $24 \%$ for the A-4 soil treated with $10 \% \mathrm{CKD}$. Increasing the content of CKD to $16 \%$ reduced the weight loss to $19.5 \%$. These losses are greater than the PCA(1971)recommended allowable weight loss for A-4 soil as shown in Table 5. The $A-1-b$ and $A-2-4$ soils with $10 \%$ CKD show acceptable weight loss.

Table 5 Results and Limits for Weight Loss in WetDry Tests

\begin{tabular}{|c|c|c|c|c|}
\hline Soil & $\begin{array}{c}\text { CKD } \\
(\%)\end{array}$ & $\begin{array}{c}\text { Wet-dry } \\
\text { Losses } \\
(\%)\end{array}$ & $\begin{array}{c}\text { Portland } \\
\text { Cemerit* } \\
\text { Requirement } \\
(\%)\end{array}$ & $\begin{array}{l}\text { Limit* } \\
\text { of Losses } \\
(\%)\end{array}$ \\
\hline$A-1-b$ & $\begin{array}{l}10 \\
16 \\
\end{array}$ & $\begin{array}{r}10 \\
5.5 \\
\end{array}$ & $5-8$ & $\leq 14$ \\
\hline$A-2-4$ & $\begin{array}{l}10 \\
16\end{array}$ & $\begin{array}{l}11 \\
6.7 \\
\end{array}$ & $5-9$ & $\leq 14$ \\
\hline A-4 & $\begin{array}{l}10 \\
16 \\
\end{array}$ & $\begin{array}{c}24 \\
19.5\end{array}$ & $7--12$ & $\leq 10$ \\
\hline
\end{tabular}

\section{CONCLUSIONS}

An evaluation based on technical factors indicated that cement kiln dusts have significant potential to replace conventional materials for various applications in highway construction. The following conclusions can be drawn from the work completed on this research project.

1. CKD can be successfully used to stabilize soils.

2. CKD - lowers plasticity, increases $\mathrm{pH}$ value, increases optimum moisture content and lowers maximum dry density of tested soils. 
3. For the A-4 soils adding CKD dramatically increases the CBR value with increasing CKD percentage.

4. Adding CKD to tested soils increases the unconfined compressive strength of tested soils.

5. Curing tested soils further increases the uncoufined compressive strength.

\section{ACKNOWLEDGMENT}

The researchers are grateful to the SABIC (Saudi Basic Industries Corporation), for its friancial support and Al-Yammamah Cement factory for providing the $C K D$ material.

\section{REFERENCES}

[1] Al-Refeai, T.O. (1998), "Utilization of Cement Waste in Ground Modification", Proceedings of 2nd International Conference on Ground Improvement Techniques, Singapore, pp. 55-60.

[2] Al-Refeai, T.O. (2000), "Stabilization Characteristics of Cement-Kiln Dust", Proceedings of 1st International Conference on Geotechnical Geoenvironmental Eng. and Management in Lands, Al-Ain, UAE, pp. 133137.

[3] Al-Refeai, T.O. and Al-Karni (1999), "Experimental Study on the Utilization of Cement Kiln Dust for Ground Modification, Journal of King Saud University, Engineering Sciences, Vol. 11 (2), pp. 217-232.

[4] Chesner, W.H. and Eighmy, T.T., eds, (1991), 3rd Int. Conf. on Municipal Solid Waste Combustor Ash Utilization, Durham.

[5] Ciesielski, S.K. and R. J. Collins (1994), "Recycling and Use of Waste Materials and ByProducts in Highway Construction," National Cooperative Highway Research Program Synthesis of Highway Practice 199, Transportation Research Board, Washington, DC.

[6] Collins, R.J. and J.J. Emery (1983), Kiln DustFly Ash Systems for Highway Bases and Subbases. Federal Highway Administration, Report No. FHWA/RD-82/167, Washington, $D C$, September.

[7] Davis, T.A. and D.B. Hooks (1974), Study of the State of the Art of Disposal and Utilization of Waste Kiln Dust from the Cement Industry, Report of the U.S. EPA, Grant No. R-801872, Southern Research Institute, Birmingham, Alabama.

[8] Eades, J.L. and Grim, R.E., (1966), "A Quick Test to Determine Lime Requirements for Lime Stabilization", highway Research Record 139, HRB, pp. 61-72.

[9] Fatani, M.N. and Khan, A.M. (1990), "Improvement of Dune Sand Asphalt Mixes for
Pavement Bases", Journal of King Abdulaziz University, Engineering Sciences, Vol. 2, pp. 3947.

[10] Hausmann, M.R. (1990). Engineering Principle of Ground Modification. McGraw-Hill, Inc. New York, N.Y.

[11] Ingles, O.G. and Metcalf, J.B. (1977), "Soil Stabilization Principles and Practice", Butterworths Pty. Limited.

[12] Kamon, M., and Katusmi, T., (1994), "Civil Engineering Use of Industrial Waste in Japan," Developments in Geotechnical Engineering, Balasubramaniam et al. eds. pp. 265-277.

[13] Labahn, O. " Cement Engineers Handbook. "Bauveriag GmbH. $3^{\text {rd }}$ ed., 1983

[14] MacKay, M.H. and J.J. Emery, (1994), "Stabilization/Solidification of Contaminated Soils and Sludges Using Cementitious Systems: Selected Case Histories, "Transportation Research Record No. 14, Transportation Research Board, Washington, DC.

[15] MacLean, D.J. and Lewis, W.A. (1963), "British Practice in the Design and Specification of Cement Stabilized Base and Subbase for Roads", HRB, Highway Research Record 36, pp. 56-76.

[16]Miller, G.A. and Zaman, M.M. (2000) "Field and Laboratory Evaluation of Cement Kiln Dust as a Soil Stabilizer", TRB 79th annual meeting, January 9-13, Washington, D.C.

[17]Miller, G.A., Azad, S. and Dhar, B. (1997), "The Effect of Cement Kiln Dust on the Collapse Potential of Compacted Shale", Testing Soil Mixed with .Waste or Recycled Materials, ASTM, STP 1275, pp. 232-345.

[18] Mindness, S. and J.F. Young (1981). Concrete Prentice Hall, Inc.

[19] Ola, S.A. (1978), "Geotechnical Properties and Behavior of Some Stabilized Nigerian Lateritic Soils", Quarterly Journal of Eng. Geology, Vol. 11, No. 2, pp. 145-160.

[20]PCA (1971) Soil - Cement Laboratory Handbook, Portland Cement Association.

[21] Schoroder, R.L., (1994), "The Use of Recycled Materials in Highways Cotstruction," Public Roads, Autumn, pp. 32-41.

[22] Thomson, M.R. (1968), "Lime Treated Soils for Pavement Construction", Journal of Highway Div. ASCE, Vol. 94, HW2, pp. 191-217.

[23] U.S. Environmental Protection Agency (1993), Report to Congress on Cement Kiln Dust. EPA 530-R-94-001, December.

[24] Zaman, M., Laguros, J.G. and Sayah, A. (1992), "Soil Stabilization Using Cement Kiln Dust", Proceedings of 7th International Conference on Expansive Soils, Dallas, Texas, pp. 34 $\%-351$. 